\title{
PROBLEMS OF DIFFERENTIATION OF SOCIO-ECONOMIC DEVELOPMENT IN THE GLOBAL ECONOMY
}

\author{
Marat R. Safiullin ${ }^{1}$ \\ Gulnaz M. Galeeva ${ }^{2}$ \\ Raushaniya I. Zinurova ${ }^{3}$
}

\begin{abstract}
This paper considers the differentiation of the development level of some countries of the world using different models of socio-economic development. The study consisted of several stages and was based on data published on the official websites of the World Economic Forum, the World Bank, and the International Monetary Fund. In this regard, we studied the methods for assessing the quantitative and qualitative parameters of the development of countries in the world economy. We also studied the leading countries in terms of socio-economic development, strategies and their competitive advantages, and identified priority areas for the development of the economies of countries under consideration during the analyzed period. This paper presents an analysis of
\end{abstract}

economic parameters, a comparison of national economies, their development dynamics using quantitative indicators of economic growth. According to the study, China has prospects for a great leap forward in economic development, the United States is the leader in many respects, and Japan has slowed down in economic growth and risks continuing to suffer losses in a number of economic indicators. Chad, India, China and developed countries have strong differentiation in terms of per capita GDP growth rates according to PPPs. All this speaks of the processes of strengthening differentiation, taking place in the world economy, widening the gap in the level of life quality among countries.

\footnotetext{
${ }^{1}$ Kazan Federal University. e-mail: Marat.Safiullin@tatar.ru .Tel. (843) 233-72-77.

${ }^{2}$ Kazan Federal University. e-mail: Marat.Safiullin@tatar.ru .Tel. (843) 233-72-77.

${ }^{3}$ Kazan National Research Technological University. e-mail: rushazi@ rambler.ru. Tel. 2314326.
} 
Keywords:

socio-economic

development, investment, innovation, education, human capital, poverty problem.

\section{Introduction}

There is no single and universal methodology for assessing the differentiation of socio-economic development of countries of the world. An important source of information for assessing the socio-economic development of countries of the world is the system of national accounts. The gross domestic product is a key indicator in this system.

The methodology developed by the specialists of the World Bank Department of Environment is based on the use of sustainable development indicator. According to World Bank experts, national wealth consists of natural capital, human capital, and produced capital. A distinctive feature of this method is the accounting of human capital and natural resources.

The next methodology is the methodology of the World Bank for Reconstruction and Development. In 2000, the International Association of Income and Wealth Researchers proposed a new indicator - "national wealth per capita".

In the second half of the 1980s, it was formed a new concept of "human development index" within the framework of the UN. This index takes into account the conditions provided by the healthcare system and education for human development. Since 1990, the publication of HDI statistics for countries within the UN began.

The economic efficiency indicators best reflect the level of economic development of the country, directly or indirectly demonstrating the quality, level and state of use of all types of resources involved in production, fixed and working capital. Such indicators include: capital intensity, material intensity of GDP unit and a particular product type, labor productivity, etc.

\section{Methods}

The material for work was data from the World Bank and the International Monetary Fund. The methods for assessing the parameters of socio-economic development of countries have certain differences, and 
therefore can complement each other to

determine the differentiation level.

Table 1

Differentiation indicators of the population by income level in the countries of the world

\begin{tabular}{|l|c|c|c|}
\hline A country & $\begin{array}{c}\text { Quintile Income } \\
\text { Ratio 2010-2015 }\end{array}$ & $\begin{array}{c}\text { Palm Index } \\
2010-2015\end{array}$ & $\begin{array}{c}\text { Gini Index } \\
2010-2015\end{array}$ \\
\hline USA & 9,1 & 2 & 41,1 \\
\hline Germany & 4,6 & 1,1 & 30,1 \\
\hline France & 5,3 & 1,3 & 33,1 \\
\hline Italy & 6,7 & 1,4 & 35,2 \\
\hline Great Britain & 5,3 & 1,3 & 32,6 \\
\hline Netherlands & 4,2 & 1 & 28 \\
\hline Luxembourg & 5,9 & 1,4 & 34,8 \\
\hline Sweden & 4,2 & 0,9 & 27,3 \\
\hline Finland & 3,9 & 1 & 32,1 \\
\hline Japan & 5,4 & 1,2 & 42,2 \\
\hline China & 9,2 & 2,1 & 35,2 \\
\hline India & 5,3 & 1,5 & 63,4 \\
\hline South Africa & 27,9 & 7,1 & 43,3 \\
\hline Chad & 10 & 2,2 & 27,1 \\
\hline
\end{tabular}

From the data given in Table 1, we can draw conclusions about the state of distribution of goods between the population of different countries. It should be noted a fairly high level of uneven income distribution in the USA. The USA and Chad are approximately at the same level for five years. This paradox can be explained by large population of the USA. The indicators of China are recorded at the same level. There is no strong stratification of society into rich and poor in Europe as a whole, especially in Sweden, Finland, and the Netherlands. There is an unexpectedly low level of uneven 
distribution of goods in India. The highest level of all indices is in South Africa, where there is the highest percentage of white population in the African continent.

Currently, the development features of the former colonies and current developing countries is one of the most important topics of the modern world economy. The group of developing countries includes 103 countries in Africa, Latin America, Asia and Oceania, whose population is more than 4 billion people. The share of developing countries is approximately $37 \%$ in the world GDP. The production indicator of these countries doubled in the second half of the XX century, and their combined GDP increased by 6 times. In general, the collapse of the colonial system had a positive effect on the economies of the former colonies, as evidenced by the markedly accelerated rate of economic growth.
617

Since independence, the developing countries have tightened control over their natural resources. Some countries have recreated heavy industry, banking system, infrastructure, workforce training system, and educational system. Other countries have only strengthened all public and state institutions. India, Brazil, Mexico, Egypt work for export and export products of electronics, engineering and other manufacturing industries to a sufficient extent. They can already compete with Japan, European countries and the USA for some groups of goods.

\section{Results and discussion}

Based on the per capita GDP and production competitiveness indicators, one can assess the level of economic development of countries and compare the effectiveness and efficiency of socio-economic development models [1].

Table 2

Per capita gross domestic product at purchasing power parity, USD

\begin{tabular}{|l|l|l|l|l|l|l|l|l|}
\hline A country & 1980 & 1990 & 2000 & 2010 & 2015 & 2016 & 2017 & 2018 \\
\hline USA & 12553 & 23848 & 36318 & 48403 & 56770 & 57877 & 59895 & 62606 \\
\hline Germany & 11308 & 20810 & 29957 & 40840 & 47678 & 48843 & 50804 & 52559 \\
\hline France & 10728 & 19605 & 28470 & 37217 & 41687 & 42525 & 44168 & 45775 \\
\hline
\end{tabular}


Periódico do Núcleo de Estudos e Pesquisas sobre Gênero e Direito Centro de Ciências Jurídicas - Universidade Federal da Paraíba V. 9 - No 02 - Ano 2020 ISSN | 2179-7137 | http://periodicos.ufpb.br/ojs2/index.php/ged/index

\begin{tabular}{|l|l|l|l|l|l|l|l|l|}
\hline Italy & 10744 & 20054 & 28714 & 34759 & 36121 & 37004 & 38358 & 39637 \\
\hline Great Britain & 8853 & 17509 & 26682 & 36170 & 42145 & 43013 & 44365 & 45705 \\
\hline Netherlands & 11735 & 21157 & 33611 & 45398 & 50400 & 51783 & 53933 & 56383 \\
\hline Luxembourg & 15659 & 37012 & 65337 & 90640 & 101169 & 102325 & 103298 & 106705 \\
\hline Sweden & 10550 & 19975 & 29410 & 42057 & 48681 & 49806 & 51180 & 52984 \\
\hline Finland & 9457 & 18617 & 27512 & 38732 & 41235 & 42598 & 44492 & 46430 \\
\hline Japan & 8948 & 19861 & 26956 & 35149 & 40458 & 41155 & 42819 & 44227 \\
\hline China & 311 & 983 & 2930 & 9250 & 14372 & 15417 & 16682 & 18110 \\
\hline South Korea & 2191 & 7549 & 16517 & 29731 & 36501 & 37810 & 39548 & 41351 \\
\hline India & 559 & 1169 & 2026 & 4424 & 6264 & 6761 & 7287 & 7874 \\
\hline South Africa & 4645 & 6424 & 7731 & 11813 & 13339 & 13326 & 13552 & 13675 \\
\hline Chad & 434 & 784 & 956 & 2194 & 2650 & 2446 & 2349 & 2415 \\
\hline
\end{tabular}

According to this indicator, we can conclude about effectiveness of the American socio-economic model. A country with such a large population (327.6 million people) demonstrates how to provide its citizens with a high standard of living. Developing countries should use the example of the USA to understand the areas of economy and government that need special attention. As it has been already said in the first chapter, the main components of the American socio-economic model are as follows: freedom of the individual, private property and private enterprise.

The remaining countries of Western Europe (Germany, France,
Netherlands, Sweden, Finland, and Great Britain) generally have a similar indicator level. Japan, South Korea can also demonstrate the effectiveness of the new economic policies.

It is worth paying attention to difference in growing rates of the GDP per capita at PPPs in Chad, India, China and developed countries. All this speaks of the processes of strengthening differentiation, taking place in the world economy, widening the gap in the level of life quality among countries.

The next criterion in the analysis by the international comparison method is competitiveness [2]. 
Periódico do Núcleo de Estudos e Pesquisas sobre Gênero e Direito Centro de Ciências Jurídicas - Universidade Federal da Paraíba

V. 9 - No 02 - Ano 2020

ISSN | 2179-7137 | http://periodicos.ufpb.br/ojs2/index.php/ged/index

Table 3

Competitiveness index

\begin{tabular}{|l|l|l|l|l|l|l|l|l|}
\hline A country & 2007 & 2010 & 2013 & 2014 & 2015 & 2016 & 2017 & 2018 \\
\hline USA & 82.84 & 79.86 & 78.11 & 78.32 & 79.20 & 80.19 & 83.57 & 85.64 \\
\hline Germany & 78.31 & 76.73 & 78.25 & 78.11 & 78.40 & 78.98 & 80.71 & 82.84 \\
\hline France & 74.36 & 73.32 & 72.99 & 72.18 & 72.52 & 73.25 & 74.00 & 78.01 \\
\hline Italy & 62.43 & 61.55 & 63.65 & 62.95 & 63.12 & 63.69 & 64.86 & 70.77 \\
\hline Great Britain & 79.49 & 74.13 & 77.85 & 76.70 & 77.35 & 77.62 & 78.71 & 81.99 \\
\hline Netherlands & 76.65 & 76.05 & 78.60 & 77.50 & 77.92 & 78.64 & 80.08 & 82.38 \\
\hline Luxembourg & 70.84 & 70.91 & 72.75 & 72.67 & 73.81 & 74.28 & 74.71 & 76.63 \\
\hline Sweden & 77.75 & 78.67 & 78.96 & 78.31 & 77.26 & 77.64 & 78.86 & 81.66 \\
\hline Finland & 78.64 & 77.60 & 79.23 & 79.12 & 78.59 & 77.88 & 78.43 & 80.26 \\
\hline Japan & 78.68 & 76.71 & 77.08 & 77.11 & 78.18 & 78.09 & 78.43 & 82.47 \\
\hline China & 65.01 & 67.66 & 68.97 & 69.09 & 69.87 & 69.84 & 71.43 & 72.61 \\
\hline South Korea & 72.41 & 71.49 & 73.14 & 71.59 & 70.83 & 71.24 & 72.43 & 78.84 \\
\hline India & 63.88 & 61.47 & 61.73 & 61.14 & 60.11 & 61.58 & 65.57 & 62.02 \\
\hline South Africa & 64.90 & 62.00 & 62.44 & 62.45 & 62.15 & 62.66 & 61.71 & 60.76 \\
\hline Chad & 40.19 & 41.07 & 43.62 & 40.73 & 40.67 & 42.35 & 42.71 & 35.52 \\
\hline
\end{tabular}

According to Table 3, we can conclude which socio-economic model is most effective. The USA have the most competitive economy in terms of numbers over 11 years. Its strategy of state non-interference in the economy, the optimal legislative framework for doing business, the freedom of action of economic agents and a strict approach to social support ensured high competitiveness and development of the market economy.
The West European socioeconomic model also shows excellent results. The highest result is seen in the German submodel. This model is significantly different from the American one, but nevertheless it is not much behind in the efficiency of economic activity. The main differences are as follows: huge social support of citizens and even migrants, which translates into a large item of government spending, state regulation of 
the economy, and public responsibility of citizens for each other. The UK model, which has common features with both the American model and the German one, is only slightly behind the rating leaders.

The economies of Japan and South Korea are about as competitive as the countries of Western Europe. By their example, they show how we can achieve high results in a short time. Their new economic policy, changing the financing vector in the scientific and technical sphere, reducing the public sector in the economy raised their products and services to the world level, so they turned into Asian dragons.

Chad takes the last place not only in our sample of countries, but in the global ranking. Absolutely uncompetitive production or even its absence confirms all the typical features of the African model. The lack of internal incentives for development, the illiterate use of external assistance from the international organizations supporting third world countries are some of the many reasons why the Chadian economy has no prospects for progress.

The next method by which the veracity of socio-economic models and their effectiveness will be verified is an indicator of national wealth per capita. For analysis, we will need data on gross national income of PPP and population of countries. When analyzing the data from Table 3 and Table 4 through the criterion of the indicator of national wealth per capita, it is noticeable that the rate of capital growth is lower than population growth. The authors of these indicators interpret this as a lack of enhanced sustainable development in these countries. It is worth recalling that the attitude towards this method has become skeptical after the study results, in which the most developed countries did not get into the top ten. In this case, let us use the method of international economic comparison of the selected indicator [3]. 
Periódico do Núcleo de Estudos e Pesquisas sobre Gênero e Direito Centro de Ciências Jurídicas - Universidade Federal da Paraíba V. 9 - No 02 - Ano 2020 ISSN | 2179-7137 | http://periodicos.ufpb.br/ojs2/index.php/ged/index

\begin{tabular}{|l|c|l|l|l|l|l|l|}
\hline A country & 1990 & 2000 & 2010 & 2015 & 2016 & 2017 & $\begin{array}{l}\text { Average } \\
\text { annual } \\
\text { growth, } \%\end{array}$ \\
\hline USA & 23730 & 36930 & 48900 & 58300 & 58960 & 61120 & 22,41 \\
\hline Germany & 19740 & 27120 & 39960 & 49010 & 50910 & 53660 & 23,33 \\
\hline France & 17700 & 26700 & 36730 & 41720 & 42840 & 45120 & 22,00 \\
\hline Italy & 18320 & 26920 & 34940 & 36640 & 39140 & 41150 & 18,71 \\
\hline Great Britain & 16760 & 26230 & 48900 & 41090 & 41900 & 44090 & 26,83 \\
\hline Netherlands & 18720 & 32100 & 45170 & 50340 & 50580 & 54650 & 26,43 \\
\hline Luxembourg & 28820 & 49180 & 61750 & 69470 & 71350 & 76300 & 23,67 \\
\hline Sweden & 19890 & 29280 & 42780 & 49060 & 49620 & 52130 & 22,84 \\
\hline Finland & 17830 & 26590 & 39260 & 42530 & 44360 & 46880 & 23,02 \\
\hline Japan & 19740 & 27220 & 35890 & 41990 & 42630 & 43540 & 18,08 \\
\hline China & 990 & 2900 & 9290 & 14440 & 15500 & 16800 & 96,89 \\
\hline India & 1220 & 2130 & 4230 & 6060 & 6510 & 6950 & 46,13 \\
\hline South Africa & 6040 & 7380 & 11400 & 12890 & 12900 & 13120 & 18,30 \\
\hline Chad & 710 & 780 & 1820 & 2140 & 1990 & 1920 & 30,05 \\
\hline
\end{tabular}

According to the data from

Table 5, the countries are divided into 2 types of average annual population growth: high and low growth. The highest population growth rates are in
India, South Africa, Luxembourg and the USA. Germany and Japan have the lowest rate, which will affect the share of the able-bodied population and the rate of economic growth [3].

Table 5

Population, mln.

\begin{tabular}{|l|c|c|l|l|l|l|l|}
\hline A country & 1990 & 2000 & 2010 & 2015 & 2016 & 2018 & $\begin{array}{l}\text { Average } \\
\text { annual } \\
\text { growth, } \%\end{array}$ \\
\hline USA & 250 & 282 & 309,7 & 320,930 & 323,225 & 325,32 & 5,52 \\
\hline Germany & 78,949 & 81,457 & 80,28 & 81,687 & 82,349 & 82,657 & 0,93 \\
\hline
\end{tabular}


Periódico do Núcleo de Estudos e Pesquisas sobre Gênero e Direito Centro de Ciências Jurídicas - Universidade Federal da Paraíba V. 9 - No 02 - Ano 2020 ISSN | 2179-7137 | http://periodicos.ufpb.br/ojs2/index.php/ged/index

\begin{tabular}{|l|c|c|c|c|c|c|c|}
\hline France & 56,577 & 58,858 & 62,765 & 64,301 & 64,469 & 64,618 & 2,72 \\
\hline Italy & 56,694 & 56,924 & 59,707 & 60,796 & 60,666 & 60,589 & 1,36 \\
\hline Great Britain & 57,077 & 58,886 & 62,760 & 65,11 & 65,648 & 66 & 2,98 \\
\hline Netherlands & 14,952 & 15,926 & 16,615 & 16,937 & 17 & 17,140 & 2,79 \\
\hline Luxembourg & 0,382 & 0,434 & 0,502 & 0,563 & 0,576 & 0,591 & 9,27 \\
\hline Sweden & 8,591 & 8,883 & 9,416 & 9,851 & 9,995 & 10,120 & 3,35 \\
\hline Finland & 4,974 & 5,171 & 5,351 & 5,472 & 5,487 & 5,503 & 2,05 \\
\hline Japan & 123,4 & 126,8 & 127,5 & 126,978 & 126,960 & 126,74 & 0,54 \\
\hline China & 1143,3 & 1267,43 & 1340,9 & 1374,62 & 1382,71 & 1390 & 4,06 \\
\hline India & 847,5 & 1029,5 & 1200,6 & 1282,918 & 1299,796 & 1316,8 & 9,52 \\
\hline South Africa & 36,79 & 44,9 & 50,850 & 54,75 & 55,62 & 56,522 & 9,24 \\
\hline Chad & 5,648 & 7,478 & 10,223 & 11,566 & 11,855 & 12,185 & 5,52 \\
\hline
\end{tabular}

The next method that we will use was developed by the UN. The human development index takes into account the conditions provided by the health and education system for human development [4].

Table 6

Human Development Index

\begin{tabular}{|l|l|l|l|l|l|l|}
\hline A country & 1990 & 2000 & 2010 & 2015 & 2016 & 2018 \\
\hline USA & 0,860 & 0,885 & 0,914 & 0,920 & 0,922 & 0,924 \\
\hline Germany & 0,801 & 0,868 & 0,921 & 0,933 & 0,934 & 0,936 \\
\hline France & 0,779 & 0,849 & 0,882 & 0,898 & 0,899 & 0,901 \\
\hline Italy & 0,769 & 0,830 & 0,870 & 0,876 & 0,878 & 0,880 \\
\hline Great Britain & 0,775 & 0,867 & 0,905 & 0,918 & 0,920 & 0,922 \\
\hline Netherlands & 0,829 & 0,876 & 0,910 & 0,926 & 0,928 & 0,931 \\
\hline Luxembourg & 0,782 & 0,855 & 0,889 & 0,899 & 0,904 & 0,904 \\
\hline Sweden & 0,816 & 0,897 & 0,905 & 0,929 & 0,932 & 0,933 \\
\hline
\end{tabular}


ISSN | 2179-7137 | http://periodicos.ufpb.br/ojs2/index.php/ged/index

\begin{tabular}{|l|l|l|l|l|l|l|}
\hline Finland & 0,784 & 0,858 & 0,903 & 0,915 & 0,918 & 0,920 \\
\hline Japan & 0,816 & 0,855 & 0,885 & 0,905 & 0,907 & 0,909 \\
\hline China & 0,502 & 0,594 & 0,706 & 0,743 & 0,748 & 0,752 \\
\hline South Korea & 0,728 & 0,817 & 0,884 & 0,898 & 0,900 & 0,903 \\
\hline India & 0,427 & 0,493 & 0,581 & 0,627 & 0,636 & 0,640 \\
\hline South Africa & 0,618 & 0,630 & 0,649 & 0,692 & 0,696 & 0,699 \\
\hline Chad & - & 0,299 & 0,371 & 0,407 & 0,405 & 0,404 \\
\hline
\end{tabular}

According to the data from

Table 5, the country with the highest human potential is Germany, followed by Sweden with a slight lag. In general, this indicator is very high throughout Western Europe, which indicates the effectiveness of investing in human capital, healthcare, educational environment and social security. The HDI is not much different and rarely drops below 0.9 in all developed countries.

Asian countries also demonstrate their awareness of the importance of human resource development [5].. However, in terms of numbers, China is noticeably behind its neighbors This may be due to the high population and internal differentiation of the level of socio-economic development and the stratification of society into rich and poor.
South Africa and India have average HDIs, but little progress is noticeable over the years. These countries have the prospect of further development. In India, the former colony of Great Britain, a large proportion of the population speaks English, which laid the foundation for highly qualified personnel and a fairly good level of education [6]. This causes a conclusion about the prospects for the development of international cooperation. However, it is hampered by high internal differentiation of the social security of the population.

Chad, as expected, ranks last. A country that is unlikely to be able to provide its domestic consumption without external support does not focus on the development of human capital.

\section{Summary}


A comparative analysis of the state of the problem of differentiation of the socio-economic level of the countries of the world reflects how the number of countries, suffering from low development rates and high poverty, has changed over 8 years [7]. Table 7 shows the changes in indicators characterizing the poverty level in the world: the number of poor countries with a large share of the population living on less than $\$ 5.5$; the number of countries with low HDI, the number of countries with low GDP per capita, the number of countries with low prosperity index and the number of countries with a gross national income per capita below the average.

The dynamics of indicators of the degree of differentiation of the socioeconomic level

\begin{tabular}{|l|c|c|}
\hline \multicolumn{1}{|c|}{ Indicators } & 2010 & 2018 \\
\hline $\begin{array}{l}\text { The number of poor } \\
\text { countries with a large share } \\
\text { of the population living on } \\
\text { less than \$ 5.5 }\end{array}$ & 74 & 24 \\
\hline HDI =<0.5 & 35 & 25 \\
\hline $\begin{array}{l}\text { GDP per capita below \$ } \\
2,000\end{array}$ & 29 & 83 \\
\hline $\begin{array}{l}\text { GDP per capita below world } \\
\text { average }\end{array}$ & 99 & 41 \\
\hline Prosperity Index <55 & 51 & 48 \\
\hline $\begin{array}{l}\text { Gross national income per } \\
\text { capita of less than } \$ 5,000\end{array}$ & 61 & \\
\hline
\end{tabular}

Table 7 presents the dynamics of indicators characterizing differentiation of the level of socioeconomic development of the countries of the world. On their basis, one can see how the situation in the world has changed with the distribution of wealth among countries and the standard of 
living [8,9]. In 2018, the number of poor countries with a large share of the population living on less than $\$ 5.5$ has decreased by 50 countries since 2010 . The countries with HDI below 0.5 decreased by 10 . This indicates an increase in life expectancy, an increase in the education level of the population and GDP per capita at PPPs. The latter conclusion is also confirmed by the international statistics, which confirms the reduction of countries with low GDP per capita: among countries with less than $\$ 2,000$ per person - by 8 countries, among countries with a figure below the global average - by 16 countries. The number of countries with a low prosperity index has decreased by 10 in 8 years, which means increasing social welfare in poor countries [10]. The number of countries with low GNI per capita decreased by 13 from 2010 to 2018.

\section{Conclusions}

In general, according to the analysis, the situation is being improved, the number of poor countries is declining, the human capital is developing, and the education level of the population is growing in the world.
An increase in the education of the population is one of the fundamental measures for economic growth and development [11]. According to the UN studies, the world's population is becoming more educated every year. By 2000, the number of people without basic education dropped to 25\%; in 1960 this figure was $36 \%$ [12]. The Organization of Economic Cooperation and Development revealed that more than $90 \%$ of educational institutions are funded by the state at its own expense in the developed countries in its studies on educational trends. Private funding sources sponsor higher education. We also revealed a direct relationship between the education level in the country and GDP. In the future, the growth of GDP and economic development indicators indicates an increase in life expectancy and the quality of public health.

\section{Acknowledgements}

The publication was prepared within the framework of the research project No. 19-010-00211 supported by the Russian Foundation for Basic Research (RFBR). 
The work is performed according to the Russian Government Program of Competitive Growth of Kazan Federal University.

This work is performed at the expense of the subsidy allocated to Kazan State University for the fulfillment of the state task in the field of scientific activity

(No. 26.8732.2017/BCH (Russian: $26.8732 .2017 /$ БЧ)

\section{Bibliography}

International Monetary Fund. URL: https://www.imf.org/en/data\#data (access date: 01.05.2019).

World Economic Forum [Electronic resource] - The official website of the World Economic Forum. - Access mode: https://www.weforum.org, free.

\section{World Bank Group [Electronic} Resource] - The official website of the World Bank Group. - Access mode: http://www.worldbank.org, free.

United Nations Development Programs. [Electronic resource] - Official website of the United Nations. - Access mode: https://www.undp.org/content/undp/en/ home.html, free.

Reshetnikova, E. G. Problems of measuring socio-economic differentiation // Bulletin of the Saratov State Socio-Economic University. 2017. No. 3. URL: https://cyberleninka.ru/article/n/problem y-izmereniya-sotsialnoekonomicheskoy-differentsiatsii (access date: 05.05.2019).

Shevyakin, A.S. Features of reproduction and use of labor resources in the conditions of increasing their differentiation // SISP. 2016. No. 1. [Electronic esource] URL: https://cyberleninka.ru/article/n/osobenn osti-vosproizvodstva-i-ispolzovaniyatrudovyh-resursov-v-usloviyahnarastaniya-ih-differentsiatsii (access date: 01.05.2019).

G.M. Galeeva, R.I. Zinurova Technological modernization of industry // Social Sciences and Interdisciplinary Behavior: The 4th International Congress on Interdisciplinary Behavior and Social Science (ICIBSoS 2015), pp.217-221 
Ivanov, M.E., Galeeva, G.M.

Diversification of sources of external financing the real economy in terms of institutional transformation Journal of Economics and Economic Education Research, Volume: 17 Issue: Special Issue 2, pp. $415-421$.

Safiullin, M.R., Elshin, L.A., Prygunova, M.I. Methodological Approaches to Assess the Stability and Global Competitiveness of the Regions Under the Macroeconomic Instability Conditions // Mediterranean Journal of Social Sciences 6(3), 2015. pp. 524-531

Galeeva, G.M., Paiduganova, I.V., Zagladina, E.N. Modern problems of investment cooperation development in the supply chain of the world economy // International Journal of Supply Chain Management 7(6), 2018. pp. 536-539

Sayfudinova, N.Z., Safiullin, M.R., Safiullin, A.R., Zainullina, M.R. Modeling of economic system of the development of the russian federation system // Journal of Economics and Economic Education Research 17(SpecialIssue2), 2016. pp. 334-346.
Arlington, VA National Science Board. 2016. Arlington, VA: National Science Foundation Science and Engineering Indicators 2016 (NSB-2016-1), p. 4/4546 